\title{
Socio-Economic Effects of Load Shedding on Poor Urban Households and Small Business Enterprises in Lusaka, Zambia
}

\author{
Bridget Bwalya Umar ${ }^{1} \&$ Chibuye Florence Kunda-Wamuwi ${ }^{1}$ \\ ${ }^{1}$ School of Natural Sciences, University of Zambia, Lusaka, Zambia \\ Correspondence: Bridget Bwalya Umar, School of Natural Sciences, University of Zambia, Lusaka, 10101, \\ Zambia. Tel: 260-211-290-603. E-mail: brigt2001@yahoo.co.uk
}

Received: June 24, 2019

Accepted: July 27, 2019

Online Published: August 5, 2019

doi:10.5539/eer.v9n2p20

URL: https://doi.org/10.5539/eer.v9n2p20

\begin{abstract}
Zambia has in the recent past witnessed an increase in economic activities which has led to an increased energy demand. This increased demand for energy has overshot the hydroelectric power generating capacity. Consequently, the national power utility company, the Zambia Electricity Supply Corporation (ZESCO) instituted nationwide load shedding schedules that last up to 12 hours daily. This development has potentially far reaching social and economic effects on the lives and operations of poor urban residents and small scale business enterprises (SMEs) that routinely depend on stable access to electricity. With a focus on two low income residential areas, namely $\mathrm{Ng}$ 'ombe and Kalingalinga residential areas, this study explored how residents and SMEs of the capital city, Lusaka have been affected by the recent spate of load shedding in the city. A total of 200 households and 14 SMEs from Ng'ombe and Kalingalinga were interviewed. Results show that load shedding, which occurs daily in the two study sites has caused massive disruptions to the daily lives and operations of the households and small businesses respectively. Over time, the load shedding phenomena has gotten worse and become a major political issue, reflecting the hardships for households and businesses in Zambia. On this basis, this study recommends that the government provides subsidies on alternative energy appliances such as portable diesel solar generators for small business enterprises and more favourable electric tariff rates for business that shift their manufacturing activities to night time so as to reduce demand for electricity during peak periods.
\end{abstract}

Keywords: load shedding, socio-economic effects, poor urban households, small business enterprises

\section{Introduction}

\subsection{A global Overview of Electricity Supply and Demad}

A secure and uninterrupted supply of electrical energy is essential for any economy to function. As economies grow, the demand for electrical energy grows in line with rising populations, industrialization, and rising incomes. In most areas, the rising demand for electrical energy invariably outstrips supply, leading to power outages and rationing, a phenomenon commonly referred to as load shedding. By definition, load shedding is the method of deliberately reducing demand (load) on the energy generation system by temporarily switching off distribution of energy to different geographical areas (Business Dictionary, 2016). When there is insufficient power station capacity to supply the demand from all the customers, the electricity system becomes unbalanced, which can cause it to trip out country wide, causing a blackout which can take several days to restore (City of Capetown, 2016).

At a global scale, developed countries have generally enjoyed a high degree of electricity supply security due to substantive investment in electricity generation capacity. On the other hand, only about a third of the households in sub-Saharan Africa have access to electricity and up to $80 \%$ of the population depend on biomass for cooking (Gujba et al., 2012). Recent large investments in electricity generation capacities have been spurred by the electricity crises in North America and the European Union. Between 2000 and 2001, the failure of the supply of electricity to meet demand in California lead to load shedding in some areas to prevent a failure of the entire system (De Nooij et al., 2007). Similarly, on August $14-15$, 2003, the Northeastern US and Canada experienced power outages which were highly publicized and lead to the high criticism of the US power system to the point of the US power system being likened to that of a developing nation and in need of modernization (Fialka \& Schieffer, 2003 in LaCommare \& Eto., 2006). Nevertheless, contrary to the developing world, electricity 
production and distribution in the developed world are currently undergoing significant restructuring (Schmidthaler \& Reichl, 2016) to keep up with the increasing demands for electricity.

Conversely, in the developing world, investments in electricity generation capacity have failed to keep up with the rapid demand growth (Samboko et al., 2016). For this reason, most developing countries struggle with electricity shortages and constantly experience load shedding. For instance, in April 2011, the shortfall in power generation in Pakistan was in excess of 5000 mega-Watts (MW), with demand standing at 14, 475 MW while supply was at $9465 \mathrm{MW}$. The country's cities experienced load shedding for 14 hours a day while its rural areas experienced loadshedding and blackouts of up to 20 hours a day (Kessides, 2013). In Africa, the scenario is not different from that of Pakistan. Most African countries are saddled with overloaded infrastructure with sizeable capacity shortfall and are marred by unprecedented load shedding. Although it is estimated that future power shortages will lessen in Africa, the problem will still persist because development in power generation capacity is unlikely to keep up with the rising demand for power as economies grow (IEA, 2014).

More recently, several countries in Sub-Saharan Africa (SSA), Zambia inclusive, have experienced power shortages, with the regional shortage estimated at 8,247 MW (SADC 2015). This has in most instances triggered load shedding. Since early 2015, Zambia experienced a 2,100 gigawatt-hours (GWh) power shortage triggering countrywide load shedding (Samboko et al., 2016). A number of studies have been conducted on the effects of load shedding (see Bose et al., 2006; Sangvhi, 1991; Kaseke, 2012; and Sanghvi, 1991) though they have largely focused on macro level aspects. For instance, in Pakistan load shedding caused a 1.8\% (translating to Rs 9.3 billion) loss of the gross domestic product (GDP) between 1975 and 1976 (Kessides, 2013). In India, losses from load shedding amounted to US $\$ 2.7$ billion for the period 1983/1984; representing 1.5\% of the GDP, while US\$2.1 billion was lost in 1982/83 representing 2.1\% of the GDP (Sangvhi, 1991). In Zimbabwe, load shedding caused GDP losses of up to $32 \%$ for each kilowatt-hour (kWh) lost (Kaseke, 2011).

These examples albeit having a macroeconomic focus demonstrate that load shedding has potentially large effects on poor urbanites of developing countries such as Zambia. Studies conducted elsewhere have shown that load shedding causes significant disruptions in the daily lives of ordinary citizens (Kessides, 2013), and paralyses small business enterprises (Siddique et al., 2008).

\subsection{Electricity Supply and the Informal Economy in Zambia}

In the case of Zambia, a recent study by the Engineering Institution of Zambia noted that the increase in economic activities over the past several years has led to an increase in demand for energy and has put stress on the hydroelectric power generating water resource (Engineering Institution of Zambia, 2015). Consequently, the national power utility company, the Zambia Electricity Supply Corporation (ZESCO) instituted nationwide load shedding schedules that last up to 12 hours daily. This development has potentially far reaching social and economic effects on the lives and operations of poor urban residents and small scale business enterprises that routinely depend on stable access to electricity. Access to clean and reliable energy is critical to human welfare and income generation possibilities seen from a household perspective (Winkler et al., 2011). Electricity access can improve education, by extending the time for studying, and improve human welfare as a consequence of a more amenable life, once the time devoted to domestic activities decreases and spare time increases (Magnani \& Vaona, 2016). Poor urban households are mostly engaged in the urban informal economy as they have less skill, less education and less capital (Brown \& McGranahan, 2016). The informal economy is an important part of urban economies in the global South (Martinez \& Estrada, 2017). It includes a wide array of activities, from street vending to domestic service, from home-based enterprises to the informal employees of formal enterprises, and from waste picking to urban agriculture. Most residents of poor neighbourhoods in the Global South participate in the informal economy by engaging in economic activities with low barriers to entry. Ongoing trends indicate that the non-agricultural informal economy is expanding in urban areas, especially in countries experiencing rapid urbanisation (Brown \& McGranahan, 2016). This entails that its capital city, Lusaka, has an increasingly larger number of its poor residents dependent on informal activities that use electricity. Thus frequent disruptions in electricity supply or load shedding was hypothesised to disrupt socio - economic activities in the more than 43 unplanned settlements of Lusaka, Zambia. The unplanned settlements are home to 70 per cent of the city's population (Nchito, 2007).

This study therefore explored how residents and small scale business enterprises of the capital city, Lusaka have been affected by the recent spate of load shedding in the city. Focus was on effects on the poor and thus two low income residential areas were selected for the study, namely $\mathrm{Ng}$ 'ombe and Kalingalinga residential areas.

\section{Method}

This section describes in succicint detail how the study was conducted but before that, a brief description of the 
study area is provided to set the context of the study.

\subsection{Description of the Study Area}

This study was conducted in Ng'ombe and Kalingalinga residential areas of Lusaka city. Ng'ombe residential area is situated on the north-eastern periphery of the built up areas of Lusaka and it borders Roma Township, one of the high-income areas of Lusaka. It covers a total area of $15.75 \mathrm{Km}^{2}$. Kalingalinga residential area is located on the eastern part of the city and stretches across an area of $10.23 \mathrm{~km}^{2}$. The two study sites lie within a radius of about 15 Kilometers from the Central Business District (Figure 1).

Ng'ombe and Kalingalinga started out as unplanned and illegal settlements but were later regularized and declared as statutory improvement areas. They are characterized by high population densities i.e. 4222 persons per square kilometer and 3826 persons per square kilometer respectively (CSO, 2010). Kalingalinga has a total population of 39139 of which 5962 persons are poor while $\mathrm{Ng}$ 'ombe has a total population of 66492 of which 13668 are poor (World Bank, 2015).

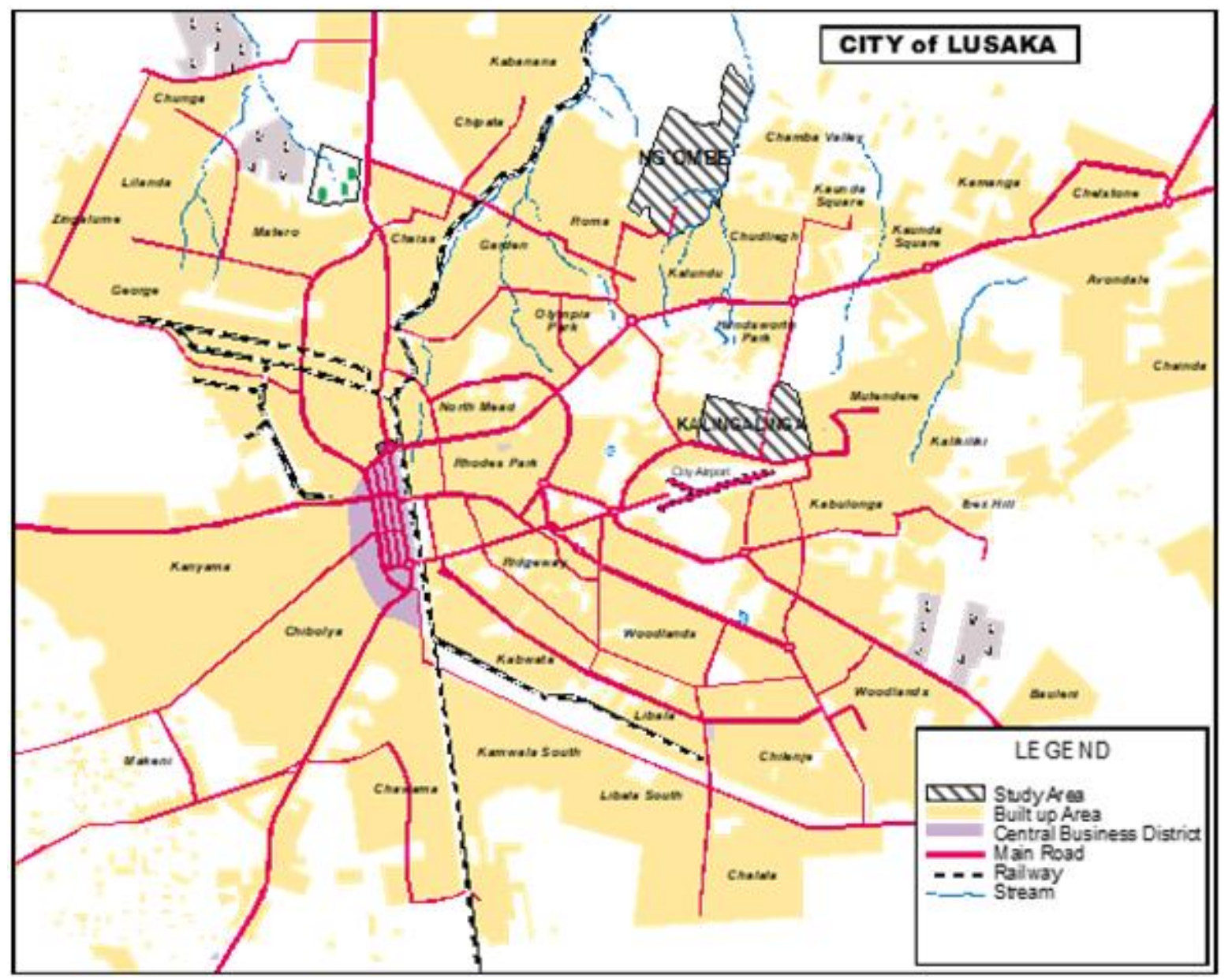

Figure 1. Location of Kalingalinga and Ng'ombe residential areas, Lusaka Zambia

The majority of residents in Ng'ombe and Kalingalinga are engaged in informal manufacturing (welding, wood products etc.), informal trading, while some work as domestic workers in high and medium income households in the surrounding neighborhoods. Poverty is quite prominent in the two areas with Kalingalinga having a 15.2\% poverty incidence while that of $\mathrm{Ng}$ 'ombe is at $20.6 \%$ (CSO, 2010). Similar to other poor neighbourhoods in Lusaka city, Ng'ombe and Kalingalinga face a number of social challenges including HIV/AIDS, low levels of education, unemployment, rapid population growth, increasing inequality between the rich and poor and most recently, long hours of load shedding. Load shedding is very prominent in Lusaka and the unplanned settlements like Ng'ombe and Kalingalinga are the worst hit. 


\subsection{Sampling Procedures}

Field work for this study was conducted in August 2015 and February 2016. A total of 200 households and 14 small business enterprises were interviewed. Of the 200 households interviewed, 120 were from Kalingalinga residential area while 80 were from Ng'ombe. For Kalingalinga area, ten households were sampled per zone for a total of 12 zones. The residential area is divided into zones for administration purposes by the local authority. The first house in each zone was selected purposefully, at the beginning of the transect, and then every fifth house along a zig-zag transect provided it has electricity connections, without which, the next house was selected. For Ng'ombe residential area, four transect walks were conducted from the centre of the area in the northern, southern, western and eastern directions. Using interval sampling, twenty households were then sampled at an interval of five houses along each transect. Purposive sampling was used to select a wide range of small business enterprises that depend on electricity for their operations. A total of 14 small business enterprises were selected. These included three butcheries, one metal fabrication business, two hair salons, two bakeries, two supermarkets, a bar, a hardware shop, an internet café and a stationery shop.

\subsection{Data Collection and Analysis Methods}

Semi structured interviews were conducted with adult members of the sampled electrified households and the small business enterprises. Respondents were asked questions on how frequently they experienced load shedding and how load shedding has affected their social and economic activites. Representatives of the small business enterprises were asked to explain in what ways and to what extents their businesses have been affected by load shedding. The interviews were conducted either in English or the local dialect Nyanja depending on the language the respondent or key informant was most familiar with. Content analysis was used to analyse the data with the aid of the qualitative data analysis software QDA Miner 3.2 (Provalis Research, 2013). The responses given by the respondents to the open-ended questions were read through several times by the two authors. Categories were then created and category names assigned based on the responses from the data. Efforts were made to ensure that the categories were exhaustive and mutually exclusive. In cases where the authors felt that the categories were repetitive or overlapping, revisions were made by combining such categories. Each response was then examined and placed in the relevant category. Frequencies for each category were then calculated and presented as percentages.

\section{Results and Discussion}

Almost half (48\%) of the respondents were aged between 20 and 30 years, while the rest where above 30 years old. Most of the respondents (64\%) were women and the rest (36\%) were men. The higher percentage of women respondents was probably due to most men having gone out to engage in income earning activities outside the home at the times the survey was conducted, which was from mid-morning to late afternoon.

Load shedding was reported as a daily occurrence and the average load shedding duration was eight hours. It usually lasted from 06:00 -14: 00hrs, 12: 00 - 20: 00hrs, and 14: $00-22 \mathrm{hrs}$.

\subsection{Effects of Load Shedding on Households}

The commonly cited effects of load shedding on households affected the economic and social spheres of the households (Figure 2). When electricity supply is cut off, electrical appliances such as television and radios cannot be operated. As most household members spend a lot of time in front of the television or listening to the radio as they perform other activities around the house, not being able to do this was noted as an effect of load shedding by the highest percentage of the respondents. One male respondent observed that his fellow men have taken to drinking heavily from home as there is nothing else for them to do but drink. Conversely, a female respondent identified a positive outcome of load shedding on marriages: "my friend told me that her husband has changed. He doesn't go out to drink. He stays home during load shedding, they have candle light dinners, which is romantic. Load shedding has improved her marriage"

Women take longer to prepare food and also find it more challenging. There is a risk of carbon monoxide poisoning when they cook using charcoal from inside their homes as they do at night. Mothers nursing their babies cited baby care during periods of load shedding at night as hard. Additionally, infants that got ill during the night cannot be attended to at the local clinic but have to be ferried much further to a hospital. This alludes to the gendered outcomes of load shedding in the study sites. The literature on gender and energy has largely focused on the rural women, and the challenges they face in accessing energy, particularly wood fuel (Wamukonya, 2002). The gender and energy debates have been captured in the rural household economics and labour discourses with time spent and drudgery suffered by rural women in gathering fuelwood for household cooking needs as the main problems (UNDP, 1995). As this study shows, poor urban women also experience 
unequitable burden compared to men albeit different from their rural counterparts. The similarity between rural and urban women with regards to energy use is that both their burdens result from their socio-cultural roles.

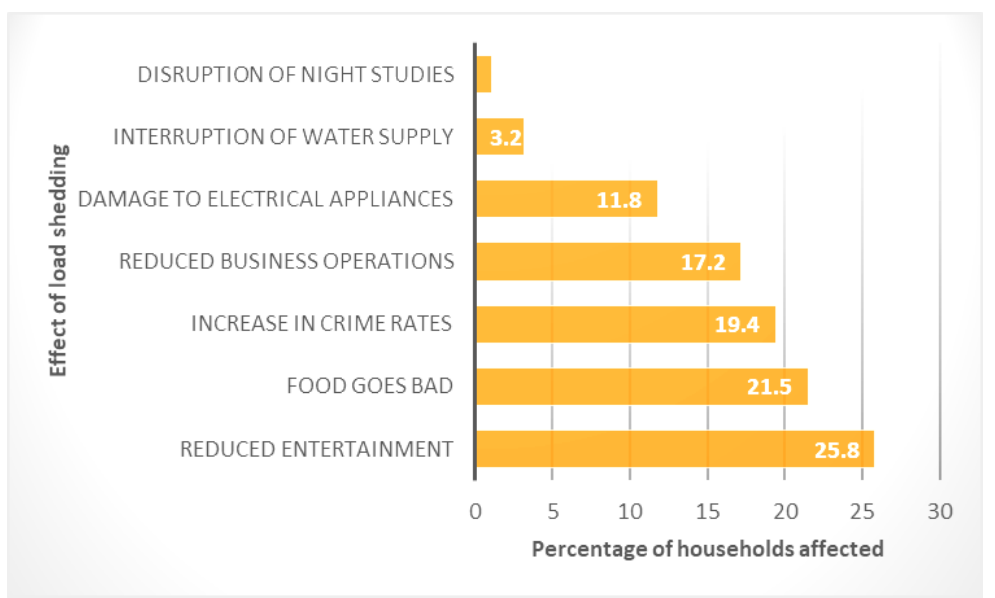

Figure 2. Effects of load shedding on households in Kalingalinga and Ng'ombe areas

Without electricity, freezing highly perishable foods is a risk as the food goes bad during prolonged and frequent periods of load shedding and has to be thrown away. Households have mitigated this challenge by reducing the quantities of perishable foods purchased and stored in freezers. Rather, they purchase as they need. The women complained that this is an added cost for the households as it necessitates more trips to supermarkets. Some men complained that the food money ends up being misallocated and thus not there when it is needed for food purchases later in the month.

On occasions when load shedding is effected at night, the residential areas are cloaked in darkness. Some residents (almost 20\%) noted that thieves take advantage of the darkness to break into homes and also attack residents that are found on the streets. Concomitantly, the households that operated businesses reported decreased sales (17.2\%) as their clients have significantly reduced on their evening purchases of basic needs. Home based businesses that depend on electricity to operate such as barber shops, hair salons, those that trade in perishable foods such as chicken, beef, milk; or cold beverages have been adversely affected. Respondents also noted increases in prices of such commodities.

Load shedding is also associated with interruption in water supply for households that access piped water from the local municipality. In such instances, it usually falls upon the women household members to ferry water from alternative sources. This adds to the labour burden of women, and a re-allocation of chores. This is in addition to the drudgery associated with cooking using braziers, which the women have to do during periods of load shedding.

Households in the two study areas use alternative energy sources during periods of load shedding (Figure 3).

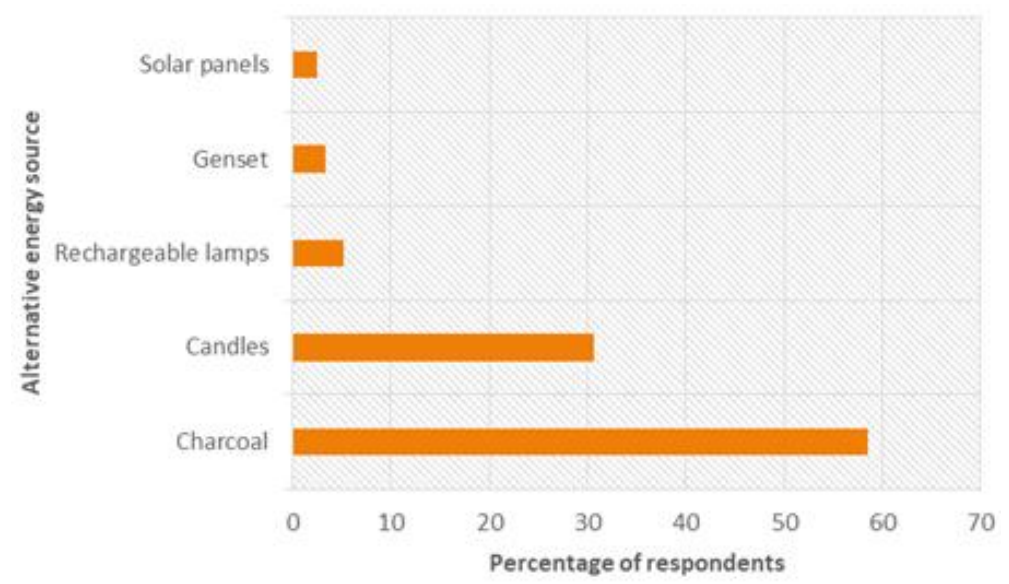

Figure 3. Alternative energy sources used during load shedding periods 
Charcoal was used for cooking by over half of the respondents while a few (3.3) had purchased portable diesel electricity generators, locally known as gensets. The gensets were too expensive to be purchased and maintained for the majority of the residents. They, thus resorted to other alternatives. This is similar to the observation made by Lovejoy (1992 in Wamukonya, 2002) that diesel gensets have been rendered largely unviable due to difficulties in accessing spare parts, technical support and high costs of diesel. Charcoal is attractive for cooking and heating among the urban poor compared to firewood: it has higher energy content, is less bulky, easier to transport, more accessible and burns more cleanly (Akpalu et al., 2011).

Table 1. Monthly expenditure on electricity before and during load shedding periods

\begin{tabular}{ccc}
\hline Amount spent (ZMW) & Before load shedding (\%) & After load shedding (\%) \\
\hline $1-100$ & 5 & 45 \\
$101-200$ & 45 & 15 \\
$201-300$ & 20 & 35 \\
$301-400$ & 20 & 5 \\
Above 400 & 10 & 0 \\
\hline
\end{tabular}

Note. 1 USD= ZMW 9.9 (date 18/05/2016).

The percentage of households that had been spending above ZMW 300 on electricity monthly reduced (Table 1) most probably because their monthly consumption of electricity declined due to load shedding. The money saved from the reduced expenditure on electricity was used on securing alternative energy sources.

The poor neighbourhoods experience longer and more frequent periods of load shedding compared to the more well to do neighbourhoods. This development potentially limits their income earning opportunities. Access to modern energy services can expand income generating activities that greatly reduce poverty (Sovacool, 2012). Respondents from both residential areas remarked on how the residents of the richer neighbourhoods just across from theirs did not suffer their fate. One woman, working as a maid in the nearby Kabulonga residential area, one of the most affluent neighbourhoods in Lusaka intoned:

When I am at work in Kabulonga, there is electricity, but every time I come back home, its load shedding. Why is ZESCO carrying out its load shedding only on us the poor people in low income residential areas but no load shedding in Kabulonga where the rich people live?" [Interview with 37-year-old woman, Kalingalinga]

The differentiated experience has caused some resentment and distrust of the state in some of the affected residents. Several questioned why the country had continued to export electricity to several of its neighbouring countries if generation capacity had reduced to levels warranting the load shedding they were experiencing. Some older residents claimed they did not experience such high levels of power interruptions even during the 1991/1992 drought which they contended was the worst drought in the history of Zambia and thus saw no justification for current load shedding levels. Concomitantly, political sentiments were echoed with most blaming load shedding on the present government and threatening action. One female respondent warned, "We are not going to vote. The whole of Kalingalinga we have agreed that we are not going to vote. To protest against all this load shedding". A male respondent echoed her, "crime and lawlessness are exacerbated at night during load shedding. We are being killed and the government is just watching. We will act through the ballot".

\subsection{Effects of Load Shedding on Small Business Enterprises}

The three butcheries were adversely affected by the periodic load shedding which resulted in eight hours of disruption to electricity supply every day of the week. One butchery manager narrated how their business has been affected by the power cuts. He explained that butchery management had cut down on the daily wholesale purchases of fresh meat products. Since fresh meat products are very perishable, it has become risky for them to purchase them in very large quantities. He elaborated their experiences as follows;

Beef, chickens and fish change colour very quickly when electricity supply is cut off and the fridges have to be switched off. The beef especially develops a black hue which makes it look like it has gone bad even when it has not. Customers do not purchase such beef. Offals and chicken go bad very quickly so we have sopped stocking them altogether. We are also avoiding ox liver and pork [Interview with butchery manager, February 2016].

The key informant representing the second butchery explained that customers were presently purchasing fewer meat products at any given time than pre load shedding days when they used to do their monthly shopping. This is because they do not want to risk the meat products going bad in their home fridges due to long periods of load 
shedding. The owners of this butchery have responded to this development by stocking fewer meat products, and consequently also have reduced sales, and smaller profit margins. The key informant representing the third butchery observed that their sales had remained the same given that they had purchased a genset which made it possible for them to store their fresh meat products at low temperatures during periods of load shedding by the electricity utility company. Conversely, this had raised their operational costs as the genset requires daily purchases of diesel. The first two butcheries had further adapted to load shedding by reducing the working hours and purchasing dry ice (solid carbon dioxide) respectively. One butchery closes earlier during loading periods scheduled in the evening. This, the key informant explained, was because customers were very few during such periods and also due to security concerns. Residents are reluctant to go to the shops when the streets are in almost complete darkness due to fear of being attacked by thieves. For the second butchery, the use of dry ice is an added cost and is only managed at sporadic intervals.

The metal fabrication business is heavily dependent on the use of high voltage electricity for its operations and thus has been very negatively affected by the disruptions. "We look like crooks to our customers because the work is not done on time. Work that should be completed in two weeks now takes three months to be completed", lamented the business owner. He further observed that their profits had greatly reduced as they take too long to complete the works. As they charged $30 \%$ of the cost of materials for every project completed, taking long to complete projects means less income from the business. He also explained that they have been unable to purchase gensets because metal fabrication operations require high voltage electricity and only a $150 \mathrm{KV}$ capacity genset would supply the needed voltage but costs ZMW 150000 (USD14 335) which he cannot afford. He has adapted by buying more machinery and making use of the extra machinery during periods when they do have electricity. He attributed load shedding to "over dependence on hydroelectric power" and made a call for diversification of energy sources by the national power utility company.

A lady in her mid-thirties who owns a bar located within the main trading area of Kalingalinga residential area complained that it was very difficult to operate a bar without a stable supply of electricity. She reported a reduction in profits due to several inter related factors; She is facing extra costs to keep the beverages cold by having to purchase dry ice of which she needs ten packs per day. A pack of dry ice costs ZMW 27 (USD 2.6). She has invested in a genset which she uses at night to play music. The fuel for the genset has to be purchased frequently and eats into her profits. No music is played during the day. Most patrons like to listen to music as they take their drinks or play games. Without music during the day, most patrons find the bar too boring and leave after a short time, meaning they buy less beer. In the evening, the patrons leave earlier than during pre-load shedding days as they are afraid of moving along streets in pitch darkness. The streets are a magnet for thieves during night scheduled load shedding periods. Added to this, the electricity tariffs for commercial users were recently hiked by over $100 \%$ and the wholesale price of beer was also hiked. She concluded by blaming the state which she accused of being unjust in its load shedding structure as below;

Too much load shedding in our area, not so much in the rich neighbourhood, Kabulonga. We are not going to vote. The whole of Kalingalinga we have agreed that we are not going to vote. This is to protest against the incessant load shedding...my clients are scared of being attacked by thieves. They just take one beer and go home. One beer is not good for business.

The bar owner's sentiments were echoed by two local supermarket operators. They observed that customers did not buy soft drinks and beer when they were not cold. Both had reduced on the quantities and types of meat products they are retailing due to increased risks of spoilage. They have stopped selling chickens and offals and restrict themselves to fresh fish, which is also costlier to purchase as the wholesale price has gone up and there is need for dry ice which of which ten packs are needed daily. The only upside mentioned was that customers purchase more candles, but the higher sales of candles did not offset the increased costs. One supermarket uses a genset at night while the other makes do with rechargeable bulbs.

The responses from the rest of the businesses interviewed, namely bakeries, stationery shop, internet café, hardware shop, and hair salons are summarized in Table 2.

Load shedding has adversely affected the small business enterprises operating from the two study sites. Their profits have reduced due to increased operational costs and reduced sales. Although the individual losses per business may be relatively small amounts, the combined effect on the local economy is significant as small business enterprises drive the local economy and are sources of livelihoods for large segments of the urban poor. Chisanga (2016) made similar observations when he reported that in many places across Zambia, both large and small scale businesses have slowed down on production as they have to work only when there is electricity. For many commercial enterprises, unreliable and costly supplies of electricity and modern fuels impede production, 
growth and development and put severe limitations on the ability to generate higher incomes (Sokona et al., 2012; Brew-Hammaond, 2010). Manufacturing and service enterprises with modern energy can be more productive and extend the quality and range of their products, thereby creating jobs and higher wages (Kaygusuz, 2012). Improved access to energy for poorer and marginalized communities would make a significant difference in the fight against poverty (Sokona et al., 2012).

\subsection{General Observations about Load Shedding in the Study Areas}

The main concern for most respondents (both households and businesses) was lack of ZESCO's adherence to a fixed load shedding schedule, which led to unexpected disruptions and restoration of power resulting in damage to electrical appliances and food spoilages. According to de Nooij et al. (2007) the season, the day of the week and the time of day when the interruption occurs determine which activities are interrupted. The length of the interruption also determines the costs. Some effects (e.g. the loss of working hours) are proportional to the length of the interruption, while other effects will start only after a while e.g. the spoilage of food in refrigerators. Daily interruptions of up to ten hours per day have disrupted the lives and operations of households and businesses respectively. A few households $(1.3 \%)$ reported not using any alternative energy sources during periods of load shedding as they lacked financial resources to access them. Respondents also noted that most residents use biomass energy sources even without load shedding because it is too expensive for them to solely depend on electricity.

Table 2. Effects of load shedding on selected businesses

\begin{tabular}{|c|c|}
\hline BUSINESS TYPE & RESPONSES \\
\hline SALON & $\begin{array}{l}\text { - During periods of load shedding, water supply is cut off. Many work hours are lost, up to } 8 \text { hours per day. } \\
\text { For salon with genset, the purchase of fuel reduces profits but at least they can work during peak business } \\
\text { periods (Thursdays, Fridays and Saturdays). The salon without a genset reported making a meagre ZMW } 150 \\
\text { (USD14.7) the previous month, which was not even sufficient for shop rentals. } \\
\text { - They are flexible in their working hours; work longer when electricity supply is not interrupted, and also use } \\
\text { candles in the evening for services that do not require electricity e.g. plaiting of hair. }\end{array}$ \\
\hline BAKERY & $\begin{array}{l}\text { - Their dough gets spoiled as sometimes electricity supply is interrupted in the middle of baking bread and } \\
\text { other products. This, was attributed to the utility company not following its load shedding schedule. } \\
\text { - The daily quantities of bread made has reduced. Before load shedding, one bakery used to use } 30 \times 50 \mathrm{~kg} \text { bags } \\
\text { of flour in a day but now only } 12-15 \text { bags are used. } \\
\text { - It became too difficult to generate enough revenue for salaries and thus four workers (out of total } \\
\text { establishment of 12) have been laid off. } \\
\text { - One bakery has a genset which was purchased a few months before at ZMW } 9000 \text { (USD (USD882). They } \\
\text { buy fuel worth ZMW } 100 \text { (USD9.8) daily. }\end{array}$ \\
\hline $\begin{array}{l}\text { INTERNET } \\
\text { CAFE }\end{array}$ & $\begin{array}{l}\text { - The business cannot operate without electricity so they purchased a genset at a cost of ZMW } 4000 \text { (USD } \\
\text { 392), on which they spend K60 for fuel daily (USD5.9). This added cost has been offset by increasing the } \\
\text { prices of their services such as printing and internet browsing. } \\
\text { They have more clients during load shedding hours as their competitors without gensets close their shops and } \\
\text { their would-be clients come over to them. }\end{array}$ \\
\hline $\begin{array}{l}\text { STATIONERY } \\
\text { SHOP }\end{array}$ & $\begin{array}{l}\text { - Load shedding is a major challenge to the business. They need electricity to offer their printing, photocopy } \\
\text { and internet browsing services. Their business also depends on sending emails to clients frequently, which } \\
\text { they cannot do during the eight hours of load shedding every day. } \\
\text { - They found gensets to be too expensive to purchase and too noisy to operate. The respondent noted that two } \\
\text { shops close to hers already have gensets which makes her work environment unconducive as they are very } \\
\text { noisy. }\end{array}$ \\
\hline $\begin{array}{l}\text { HARDWARE } \\
\text { SHOP }\end{array}$ & $\begin{array}{l}\text { - Load shedding affects them as customers do not go to the shops during load shedding hours. } \\
\text { They are unable to test their electrical appliances for their customers during periods of load shedding, and } \\
\text { thus most of them become reluctant to purchase them. } \\
\text { They make up for the lost business by extending working hours on days when there is no load shedding in the } \\
\text { evening. } \\
\text { - An appeal was made that the electricity utility company should not load shed commercial users during the } \\
\text { day so they can run their businesses. Load shedding is having a very negative effect on the economy as the } \\
\text { small and medium business enterprises are failing to operate. }\end{array}$ \\
\hline
\end{tabular}


Load shedding has only served to increase their dependence on other energy sources. This is in line with observations made by Bhide and Monroy (2011) that lower income households prefer to use biomass for cooking and heating. As income increases, electricity and modern fuels are used for lighting, modern appliances, pumps and communication but they do not substitute cooking and heating. Only in higher groups is biomass completely substituted in household consumption. Key informants reported cancelled adult education classes due to the disruptions brought about by load shedding while some respondents lamented their children's failure to do their homework and study during evenings. This could contribute to the performance gap between school performance between children from poor neighbourhoods and from higher income households. Using electricity during evening hours can extend work and study hours, contributing to household productivity and educational achievement (Barnes et al., 2011).

Load shedding in the two study sites of Kalingalinga and Ng'ombe is a daily phenomenon and has caused massive disruptions to the daily lives and operations of the households and small businesses respectively. The households have resorted to using charcoal, candles and in a few cases, portable diesel generators to supplement their energy needs during load shedding periods which last eight hours per day. This has increased the burden of women as they use more labour in ferrying water from outside their homes as water supply is interrupted during periods of load shedding. The women also take longer to prepare meals for families and are subjected to fumes when they cook indoors at night, which they prefer to do for security reasons. Household expenditures on perishable foods have reduced to avoid spoilages during periods of load shedding. The retail prices of perishable foods such as beef, fish, milk, and chickens have also gone up, as traders have passed on the increased costs of refrigeration to the consumers. Added to these, households operating businesses that require electricity from their homes have experienced severely reduced sales.

Local businesses have been similarly affected albeit at a higher rate as they have to pay rent for their premises and they face higher risks of food spoilages. These developments have negatively affected the local economy and stirred some anti-government sentiments in the residents. Most of them perceive that the government is exporting electric power at their expense and favouring the rich of the society by not rationing electricity from their residences as frequently and for as long as it is done from theirs. Poor urban households face challenges meeting their household needs and the added energy expenses in a context of reduced income earning opportunities may potentially lead to their further impoverishment. The small businesses have to not only face a more challenging business environment, due to a downturn in the national economy characterized by high inflation rates and increased costs of operating a business but also lower income as the long periods of load shedding curtail sales for most of them. The study recommends that government provides subsidies on alternative energy appliances such as portable diesel solar generators for small business enterprises and more favourable electric tariff rates for business that shift their manufacturing activities to night time so as to reduce demand for electricity during peak periods.

\section{Acknowledgments}

We wish to thank the FGE 4705 students at the University of Zambia for their assistance in data collection.

\section{References}

Akpalu, W., Dasmani, I., \& Aglobitse, P. B. (2011). Demand for cooking fuels in a developing country: To what extent do taste and preferences matter? Energy Policy, 39(10), 6525-6531. https://doi.org/10.1016/j.enpol.2011.07.054

Barnes, D. F., Khandker, S. R., \& Samad, H. A. (2011). Energy poverty in rural Bangladesh. Energy Policy. 39(2), 894-904. https://doi.org/10.1016/j.enpol.2010.11.014

Bhide, A., \& Monroy, C. R. (2011). Energy poverty: A special focus on energy poverty in India and renewable energy technologies. Renewable and Sustainable Energy Reviews, 15(2), 1057-1066. https://doi.org/10.1016/j.rser.2010.11.044

Bose, R. K., Shukla, M., Srivastava, L., \& Yaron, G. (2006). Cost of unserved power in Karnataka, India. Energy Policy, 34(12), 1434-1447. https://doi.org/10.1016/j.enpol.2005.09.017

Brew-Hammond, A. (2010). Energy access in Africa: Challenges ahead. Energy Policy, 38, 2291-2301.

Brown, D., \& McGranahan, G. (2016). The urban informal economy, local inclusion and achieving a global green transformation. Habitat International, 53, 97-105. https://doi.org/10.1016/j.habitatint.2015.11.002

Chisanga, M. (2016). Electricity shortage and its impact on small businesses. Lusaka Times. Retrieved from https://www.lusakatimes.com/2016/04/12/electricity-shortage-impact-small-businesses/ 
De Nooij, M., Koopmans, C., \& Bijvoet, C. (2007). The value of supply security: The costs of power interruptions: Economic input for damage reduction and investment in networks. Energy Economics, 29(2), 277-295. https://doi.org/10.1016/j.eneco.2006.05.022

Dictionary. (2016). Retrieved from http://www.dictionary.com/browse/loadshedding

Growitsch, C., Malischek, R., Nick, S., \& Wetzel, H. (2013). The costs of power interruptions in Germany-an Assessment in the light of the Energiewende (No. 2013-7). Energiewirtschaftliches Institut an der Universitaet zu Koeln (EWI).

Gujba, H., Thornes, S., Mulugetta, Y., Rai, K., \& Sokona, Y. (2012). Financing low carbon energy access in Africa. Energy Policy, 47, 71-78. https://doi.org/10.1016/j.enpol.2012.03.071

IEA. (2014). World Energy Outlook. Paris: International Energy Agency. Retrieved from http://www.iea.org

Kaseke, N., \& Hosking, S. (2012). An Estimate of the Cost of Electricity Outages in Zimbabwe. International Journal of Physical and Social Sciences, 2(6), 207-237.

Kessides, I.N., 2013. Chaos in power: Pakistan's electricity crisis. Energy policy, 55, .271-285. doi: https://doi.org/10.1016/j.enpol.2012.12.005.

LaCommare, K. H., \& Eto, J. H. (2006). Cost of power interruptions to electricity consumers in the United States (US). Energy, 31(12), 1845-1855. https://doi.org/10.1016/j.energy.2006.02.008.

Magnani, N., \& Vaona, A. (2016). Access to electricity and socio-economic characteristics: Panel data evidence at the country level. Energy, 103, 447-455. https://doi.org/10.1016/j.energy.2016.02.106

Martínez, L., Short, J. R., \& Estrada, D. (2017). The urban informal economy: Street vendors in Cali, Colombia. Cities, 66, 34-43. https://doi.org/10.1016/j.cities.2017.03.010.

Nchito, W. S. (2007). Flood risk in unplanned settlements in Lusaka. Environment and Urbanization, 19(2), 539551. https://doi.org/10.1177/0956247807082835.

SADC. (2015). Press Release of the 34th Meeting of SADC Energy Ministers. Johannesburg, South Africa. Retrieved from http://www.eskom.co.za/news/Documents/34thEOEM_Sandton24Jul2015.pdf

Samboko, P., Chapoto, A., Kabwe, S., Mofya-Mukuka, R., Mweemba, B., \& Munsaka, E. (2016). The Impact of Power Rationing on Zambia's Agricultural Sector.

Sanghvi, A. P. (1991). Power shortages in developing countries: impacts and policy implications. Energy Policy, 19(5), 425-440. https://doi.org/10.1016/0301-4215(91)90020-O

Schmidthaler, M., \& Reichl, J. (2016). Assessing the socio-economic effects of power outages ad hoc. Computer Science-Research and Development, 31(3), 157-161. https://doi.org/10.1007/s00450-014-0281-9

Siddiqui, R., Jalil, H. H., Nasir, M., Malik, W. S., \& Khalid, M. (2008). The cost of unserved energy: Evidence from selected industrial cities of Pakistan. The Pakistan Development Review, 227-246. http://www.jstor.org/stable/23234709

Sokona, Y., Mulugetta, Y., \& Gujba, H. (2012). Widening energy access in Africa: Towards energy transition. Energy Policy, 47, 3-10. https://doi.org/10.1016/j.enpol.2012.03.040.

Sovacool, B. K. (2012). The Political economy of energy poverty: A review of key challenges. Energy for Sustainable Development, 16(3), 272-282. https://doi.org/10.1016/j.esd.2012.05.006.

UN. (1995). Beijing declaration and platform for action. United Nations. New York.

Winkler, H., Simões, A. F., Rovere, E. L. 1., Alam, M., Rahman, A., \& Mwakasonda, S. (2011). Access and Affordability of Electricity in Developing Countries. World Development, 39(6), 1037-1050. https://doi.org/10.1016/j.worlddev.2010.02.021.

\section{Copyrights}

Copyright for this article is retained by the author(s), with first publication rights granted to the journal.

This is an open-access article distributed under the terms and conditions of the Creative Commons Attribution license (http://creativecommons.org/licenses/by/4.0/). 